MONTREAL AT WAR

1914-1918 


\section{THE CANADIAN EXPERIENCE OF WAR}

\section{Series Editor: Mark Humphries}

This series of monographs, essay collections, and edited primary sources illuminates connections between war and society in Canada, focusing on military operations as well as the experience of civilians and non-combatants. It is supported by funding from the Laurier Centre for Military Strategic and Disarmament Studies (LCMSDS) at Wilfrid Laurier University. 

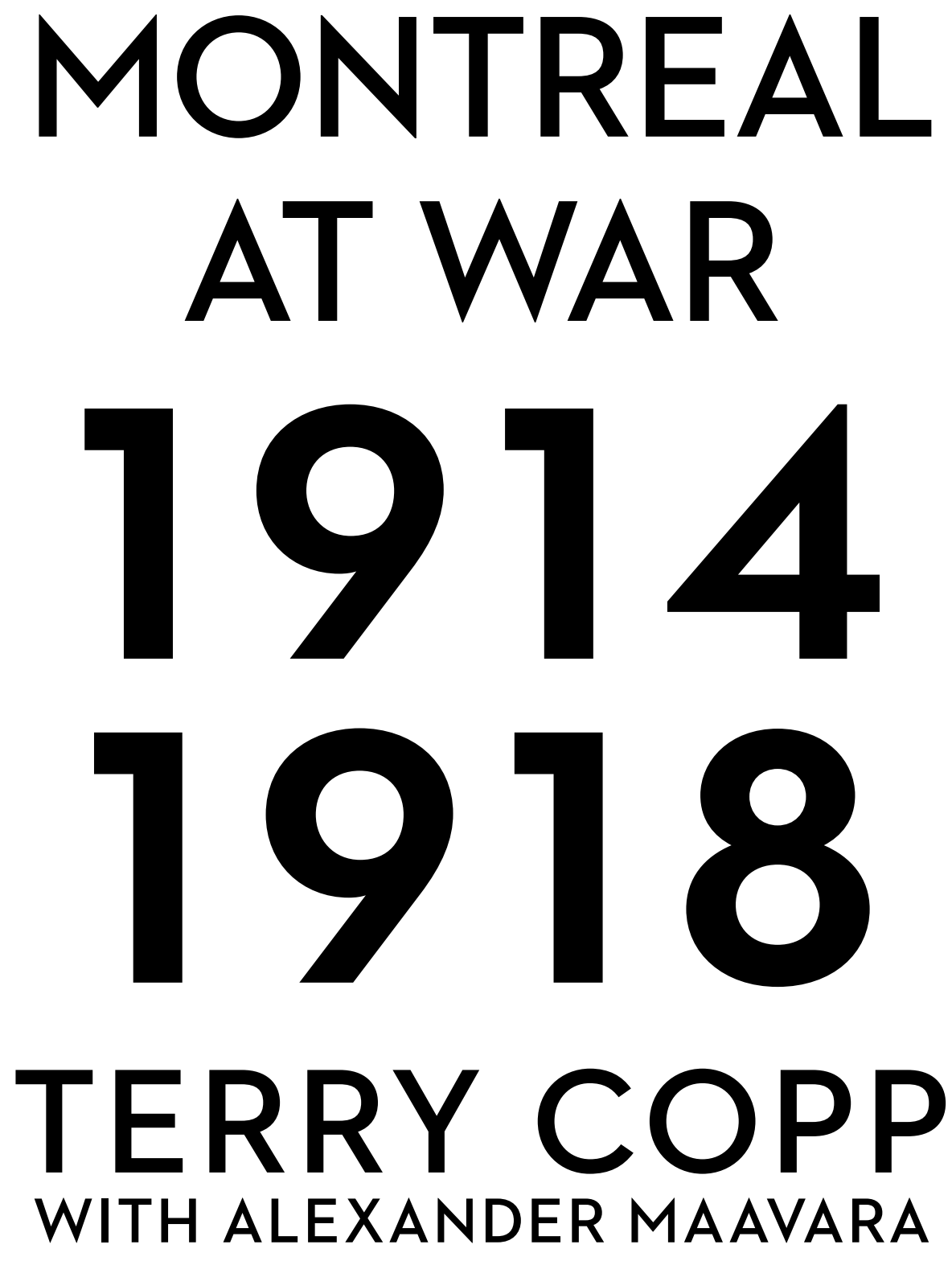

UNIVERSITY OF TORONTO PRESS

Toronto Buffalo London 
(C) University of Toronto Press 2022

Toronto Buffalo London

utorontopress.com

Printed in Canada

ISBN 978-1-4875-4154-5 (cloth)

ISBN 978-1-4875-4157-6 (EPUB)

ISBN 978-1-4875-4155-2 (paper)

ISBN 978-1-4875-4156-9 (PDF)

\section{Library and Archives Canada Cataloguing in Publication}

Title: Montreal at War, 1914-1918 / Terry Copp with Alexander Maavara.

Names: Copp, Terry, author. I Maavara, Alexander, author.

Description: Includes bibliographical references and index.

Identifiers: Canadiana (print) 20210287179 | Canadiana (ebook) 20210287217 |

ISBN 9781487541552 (paper) I ISBN 9781487541545 (cloth) |

ISBN 9781487541576 (EPUB) I ISBN 9781487541569 (PDF)

Subjects: LCSH: World War, 1914-1918 - Québec (Province) - Montréal.

Classification: LCC D547.C2 C575 2022 I DDC 940.4/0971428-dc23

\section{LAURIER CENTRE \\ for MILITARY \\ STRATEGIC and \\ DISARMAMENT \\ STUDIES \\ WILFRID LAURIER UNIVERSITY}

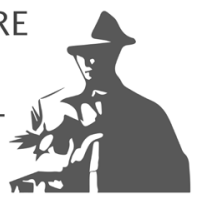

The Laurier Centre for Military Strategic and Disarmament Studies generously provided financial assistance for the publication of this book.

University of Toronto Press acknowledges the financial assistance to its publishing program of the Canada Council for the Arts and the Ontario Arts Council, an agency of the Government of Ontario.

\section{Canada Counci for the Arts}

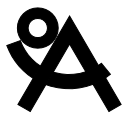

ONTARIO ARTS COUNCIL CONSEIL DES ARTS DE L'ONTARIO

an Ontarlo government agency un organlsme du gouvernement de l'Ontarlo
Funded by the Financé par le Government gouvernement of Canada

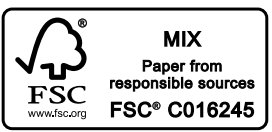

